\title{
Erratum: 20 years of Nature Biotechnology research tools
}

Anna Azvolinsky, Laura DeFrancesco, Emily Waltz \& Sarah Webb

Nat. Biotechnol. 34, 256-261; published online 10 March 2016; corrected after print 31 March 2016

In the version of this article initially published, on p. 257, Steven Salzberg's name was misspelled as "Stephen." The error has been corrected in the HTML and PDF versions of the article.

\section{Erratum: 20 years of Nature Biotechnology biomedical research}

Anna Azvolinsky, Charles Schmidt, Emily Waltz \& Sarah Webb

Nat. Biotechnol. 34, 262-266; published online 10 March 2016; corrected after print 31 March 2016

In the version of this article initially published, the leadership of the team developing ADCs was incorrectly attributed, for which Nature Biotechnology takes full responsibility. To correct this, on p.265, paragraph 3, "Shen's team at Genentech" now reads "Jagath R. Junutula (then at Genentech, now at Cellerant Therapeutics in San Carlos, CA, USA) and colleagues"; on p.266, first line, "Since then, Shen's group" now reads, "Since then, Genentech"; and the photo of Shen with the caption, "Ben-Quan Shen's group at Genentech found a way to reduce the complexity of antibody-drug conjugates" has been replaced with a photo of Junutula with the caption, "Jagath R. Junutula's group highlighted the important role of site-specific conjugation in ADC development." In addition, Kadcyla was misspelled as Kadcycla, and Adcetris as Adcentris. The errors have been corrected in the HTML and PDF versions of the article.

\section{Erratum: When biotech goes bad}

John Hodgson

Nat. Biotechnol. 34, 284-291 (2016); published online 10 March 2016; corrected after print 31 March 2016

In the version of this article initially published, on p.286, in the timeline, far right, "2008 Intercept" should have read "2008 InterMune." The error has been corrected in the HTML and PDF versions of the article.

\section{Erratum: Community crystal gazing}

Anu Acharya, Kate Bingham, Jay Bradner, Wylie Burke, R Alta Charo, Joel Cherry, André Choulika, Tony Coles, Robert Cook-Deegan, Stanley T Crook, Emilia Díaz, Brent Erickson, L Val Giddings, Sebastian Eriksson Giwa, James C Greenwood, Vishal Gulati, Sam Hall, John Harris, Jamie Heywood, Colin Hill, Jeremy Levin, Adina Mangubat, John Maraganore, Giovanni Mariggi, Barbara J Mazur, Amy L McGuire, Nathalie Moll, Jonathan Moreno, Gail Naughton, Lita Nelsen, Jane Osbourn, Daniel Perez, John Reed, Eric Schmidt, Vicki Seyfert-Margolis, Paul Stoffels, Jørgen Thorball, Tara O’Toole, Indrek Vainu, Sander van Deventer, Elias Zerhouni \& Daphne Zohar Nat. Biotechnol. 34, 276-283 (2016); published online 10 March 2016; corrected after print 31 March 2016

In the version of this article initially published, Stanley Crooke's name was misspelled as "Crook" in the author list. The error has been corrected in the HTML and PDF versions of the article.

\section{Corrigendum: Combinatorial hydrogel library enables identification of materials that mitigate the foreign body response in primates}

Arturo J Vegas, Omid Veiseh, Joshua C Doloff, Minglin Ma, Hok Hei Tam, Kaitlin Bratlie, Jie Li, Andrew R Bader, Erin Langan, Karsten Olejnik, Patrick Fenton, Jeon Woong Kang, Jennifer Hollister-Locke, Matthew A Bochenek, Alan Chiu, Sean Siebert, Katherine Tang, Siddharth Jhunjhunwala, Stephanie Aresta-Dasilva, Nimit Dholakia, Raj Thakrar, Thema Vietti, Michael Chen, Josh Cohen, Karolina Siniakowicz, Meirigeng Qi, James McGarrigle, Stephen Lyle, David M Harlan, Dale L Greiner, Jose Oberholzer, Gordon C Weir, Robert Langer \& Daniel G Anderson

Nat. Biotechnol. 34, 345-352 (2016); published online 29 January 2016; corrected after print 18 April 2016

In the version of this article initially published, one author, Adam C. Graham, his affiliation, and his contribution were omitted. In addition, two acknowledgments, to W. Salmon and J. Wyckoff, were omitted. The errors have been corrected in the HTML and PDF versions of the article. 